Interdyscyplinarny charakter badań językowych, red. J. Małocha, Kraków 2017, s. 55-80

DOI: http://dx.doi.org/10.15633/9788374386081.04

Joanna Małocha

\title{
Ewolucja adnotacji \\ we wczesnośredniowiecznych łacińskich kalendarzach liturgicznych i martyrologiach na przykładzie elogii św. Eulalii
}

Gminy chrześcijańskie z pierwszych wieków naszej ery - gnębione ustawicznie szykanami ze strony cesarstwa rzymskiego i społeczności pogańskiej - chlubiły się tymi spośród swoich członków, którzy oddali życie za wiarę. Wielką czcią otaczano również biskupów, będących niejako ojcami i przewodnikami tych społeczności. A ponieważ jednostki owe podtrzymywały niejednokrotnie wiarę całej gminy, przeto starano się na trwałe zachować pamięć o nich. Stąd też już od II stulecia powstawały spisy zmarłych hierarchów oraz miejscowych męczenników, przyporządkowujące każdemu z nich dzień, w którym dana postać miała być w sposób szczególny wspominana w trakcie celebracji liturgicznych. Przy czym dzień kommemoracji pokrywał się najczęściej z datą złożenia do grobu ciała tej osoby - depositio - co też kolei następowało zwykle w tym samym dniu co jej śmierć (rozumianym tu jako dies natalis - dzień narodzin dla nieba $)^{1}$. A ponieważ poszczególne gminy nie żyły w izolacji, lecz pozostawały

\footnotetext{
${ }^{1}$ Początkowo funkcjonowały dwa oddzielne spisy: jeden dla biskupów - Depositio episcoporum, a drugi dla męczenników - Depositio martyrum. Ponieważ jednak w starożytno-
} 
w stałej łączności ze społecznościami sąsiednimi - a nawet i tymi bardziej oddalonymi - przeto szybko zaczęto w lokalnych kalendarzach umieszczać również święta „obcych” biskupów i męczenników. W ten to sposób owe spisy nabierały cech uniwersalności i - wobec takiego ich ujednolicenia - zaczynały obowiązywać na coraz większych obszarach ${ }^{2}$.

Innym - ale wywodzącym się z kalendarzy - rodzajem tekstów wczesnochrześcijańskich, które związane były z kultem męczenników, są martyrologia. Zawarto w nich jednak nie tylko ułożone w porządku kalendarzowym wspomnienia wiernych, którzy ponieśli śmierć za wiarę, ale także zapisy odnoszące się do ascetów, biskupów czy wreszcie dobroczyńców Kościoła. Dodatkowo zaś podają one przy imieniu danej postaci krótki szkic biograficzny, często uzupełniany mniej lub bardziej panegiryczną pochwałą jej męstwa, cnót i zasług (tzw. elogium). Szybciej też, aniżeli miało to miejsce w przypadku kalendarzy, nastąpiło przekształcanie martyrologów lokalnych w zbiory o charakterze powszechnym ${ }^{3}$.

ści chrześcijańskiej właśnie hierarchowie byli najbardziej narażeni na prześladowania i oni też najczęściej ginęli śmiercią męczeńską, przeto oba kalendarze ulegały z reguły połączeniu. Szczególne zaś świadectwo praktyki upamiętniania w pierwotnym Kościele owych dat heroicznej śmierci stanowi List 12 św. Cypriana, w którym znaleźć można następujące zalecenie kartagińskiego biskupa: „Wreszcie zapisujecie też dzień ich zgonu, abyśmy mogli uroczyście obchodzić ich pamiątkę, między wspomnieniami o męczennikach. Wprawdzie nasz najwierniejszy i najoddańszy brat Tertullus między innymi objawami swej troski i opieki, jaką otacza braci we wszystkich ich potrzebach, a okazuje to i względem ich zwłok, zapisywał (daty zgonów); niech więc je dalej zapisuje i donosi mi dni, kiedy nasi błogosławieni bracia przeszli w więzieniu przez chwalebną śmierć do nieśmiertelności. Będziemy tu czcząc ich pamięć, składać dary i sprawować ofiary, a już wkrótce, z pomocą Pana będziemy to czynić razem z wami". Cyprian, Listy, tłum. O. Szołdrski, red. E. Stanula, Warszawa 1969, s. 56 (Pisma Starochrześcijańskich Pisarzy, 1). Por. J. Drabina, Chrześcijaństwo starożytne (do roku 313). Wybór tekstów źródłowych, Kraków 1983, s. 85n.

${ }^{2}$ Omówienie genezy oraz charakteru starochrześcijańskich kalendarzy kościelnych zawiera m.in.: A. François, Rok Kościelny według Mszału. Uwagi teoretyczne i praktyczne, przeł. F. Żurowska, Kraków 1949, s. 10; H. Fros, Wprowadzenie do Mszy o świętych, t. 1, Warszawa 1980, s. 29, 33; W. Schamoni, Das wahre Gesicht der Heiligen, München 1967, s. 27; Martyrologium rzymskie oraz elogia świętych i błogosławionych z niektórych martyrologiów zakonnych, oprac. P. Turbak, Kraków 1956, s. 7n.

${ }_{3}$ Zob. M. Dybowski, Liturgika, Poznań-Warszawa-Lublin 1954, s. 145; A. Witkowska, Kalendarze - martyrologia, w: Słownik wczesnochrześcijańskiego piśmiennictwa, red. J. M. Szymusiak, M. Starowieyski, Poznań 1971, s. 540.

Z pewnym uproszczeniem przyjąć można, iż specyficznym wschodnim odpowiednikiem łacińskich martyrologiów są synaksaria i menologia. Przy czym za moment osta- 
Ciekawym zjawiskiem jest proces zmian, jakim w kolejnych kalendarzach - a jeszcze wyraźniej w martyrologiach - ulegały adnotacje na temat jednej i tej samej postaci. W niniejszym artykule analizie poddane zostaną takie właśnie łacińskie zapisy traktujące o jednej z wczesnochrześcijańskich męczennic - św. Eulalii. Jej postać bowiem nie doczekała się dotychczas holistycznego opracowania, które obejmowałoby wszelkie materialne - pisane i niepisane - przejawy kultu tej świętej. A dodatkowo powstałe na jej temat teksty, mające najczęściej charakter notek encyklopedycznych, pochodzą z zachodniego kręgu badawczego. Na gruncie polskim brak zaś tłumaczeń przytoczonych niżej źródeł, a tym bardziej ich analizy ${ }^{4}$.

\section{Postać św. Eulalii w świetle tradycji}

Według najstarszych przekazów św. Eulalia przyszła na świat około 292 roku w hiszpańskiej Meridzie (Emerita Augusta) w powszechnie szanowanej, zamożnej i najprawdopodobniej chrześcijańskiej rodzinie. Już od dzieciństwa miała wykazywać skłonność do modlitewnej zadumy i kontemplacji. Gdy zaś w 304 roku - postępując zgodnie z edyktami

tecznego ukonstytuowania się kształtu owych „orientalnych” ksiąg liturgicznych, a zarazem ich upowszechnienia, z reguły przyjmowana jest połowa IX stulecia. Nie zakończyło to jednak drogi ewolucji tego typu wschodniego piśmiennictwa. Z czasem bowiem na bazie greckich menologiów powstała prawosławna minieja czetia, tj. księga wykorzystywana w liturgii cerkiewnej, zawierająca zbiór tekstów hagiograficznych, uporządkowanych według kalendarza świąt nieruchomych. Zob. H. G. Beck, Kirche und theologische Literatur im byzantinischen Reich, München 1959, s. 251n; O. Narbutt, Historia i typologia ksiagg liturgicznych bizantyńsko-słowiańskich. Zagadnienie identyfikacji według kryterium treściowego, Warszawa 1979, s. 128; K. Onasch, Liturgie und Kunst der Ostkirche in Stichworten unter Berücksichtigung der Alten Kirche, Leipzig 1981, s. 262.

${ }^{4} \mathrm{~W}$ polskiej literaturze o Eulalii pisali np.: Aureliusz Prudencjusz Klemens, Wieńce męczeńskie (Peristephanon), oprac. M. Starowieyski, Kraków 2006, s. 183-186; H. Fros, Martyrologium, czyli wspomnienia świętych przypadające na poszczególne dni roku, Warszawa 1984, s. 37; H. Fros, Wspomnienie świętych na każdy dzień roku. Martyrologium, Kraków 1992, s. 46; H. Fros, F. Sowa, Twoje imię, Kraków 1975, s. 212; H. Fros, F. Sowa, Księga imion i świętych, t. 2, Kraków 1997, kol. 215n; K. Kuźmak, M. Jacniacka, Eulalia z Méridy św., w: Encyklopedia katolicka, t. 4, red. R. Łukaszyk, L. Bieńkowski, F. Gryglewicz, Lublin 1985, kol. 1300n. 
Galeriusza i Dioklecjana - namiestnik rzymski Kalpurninus rozpoczął w regionie Lusitanii prześladowania chrześcijan, Eulalia zapragnęła oddać swe młode życie za wiarę. Dążeniom tym przeciwstawili się rodzice dziewczynki i wywieźli ją do niedalekiej wiejskiej posiadłości. Nie powstrzymało to jednak młodej bohaterki, która wymknąwszy się nocą, dotarła do Meridy i stanęła przed obliczem namiestnika. Kalpurninus miał wówczas usłyszeć z ust przyszłej męczennicy gorzkie wyrzuty i harde odpowiedzi, a część tekstów z epoki przypisuje jej nawet śmiały czyn oplucia urzędnika i podeptania pogańskiego idola. Wobec tego, iż żadne namowy, prośby ani groźby nie zdołały zmusić Eulalii do złożenia nakazanej edyktami ofiary, sędzia skazał ją na męki i śmierć. Wśród tortur, jakim została poddana, źródła wymieniają chłostę, rozdzieranie ciała żelaznymi hakami, polewanie głowy wrzącym olejem i ołowiem, sypanie soli na rany, wreszcie przypalanie pochodniami. Ostatecznie dziewczynka spłonęła żywcem na stosie lub też - według innej wersji - ścięto jej głowę. Tradycja dodaje również, iż w momencie śmierci z ciała męczennicy uleciała dusza pod postacią gołębicy. Ponieważ zaś namiestnik nakazał pozostawić obnażone ciało świętej niepogrzebane przez trzy dni na placu, cudowny opad śniegu ukrył je przed wzrokiem pogan ${ }^{5}$.

Ostatecznie wierni z Meridy pochowali Eulalię z należnym szacunkiem niedaleko miejsca męczeństwa, gdzie też wkrótce - wobec ustania prześladowań - wznieśli bazylikę. Jej kult rozwijał się w tym ośrod$\mathrm{ku}, \mathrm{a} \mathrm{z}$ czasem promieniował także i na inne rejony Europy Zachodniej, gdzie uważana jest za patronkę żeglarzy, chorych na czerwonkę, położnic, torturowanych dzieci, uciekinierów, Oviedo, Barcelony, Meridy i całej Katalonii ${ }^{6}$.

${ }^{5}$ Zob. A. Fàbrega-Grau, Eulalie de Mérida (Sainte), w: Dictionnaire d'Histoire et de Geographie ecclesiastiques, t. 15, red. A. Baudrillart, Paris 1963, kol. 1384n; H. Leclercq, Eulalie de Mérida et de Barcelone (les Saintes), w: Dictionnaire d'archéologie chrétienne et de liturgie, t. 5, cz. 1, red. F. Cabrol, H. Leclercq, Paris 1922, kol. 705-732; V. Saxer, Eulalia di Mérida, w: Dizionario patristico e di antichità cristiane, t. 1, red. A. Di Berardino, Roma 1983, kol. 1280; J. Vincke, Eulalia, hl., Jungfrau in Mérida, w: Lexikon für Theologie und Kirche, t. 3, Friburg 1957, kol. 1179n.

${ }^{6}$ Zob. C. J. M. Fernández, Manifestaciones ascéticas en la iglesia hispano-romana del siglo IV, Leon 1962, s. 147; G. Ferretto, Note storico - bibliografiche di archeologia cristiana, Città del Vaticano 1942, s. 426; I. Ortiz de Urbina, Eulalia, santa, martire, w: Enciclopedia 
Spośród źródeł pisanych zachowało się pasjo św. Eulalii z Meridy w kilku wersjach ${ }^{7}$. Męczennicy tej poświęcił także trzeci hymn ze zbioru Peristephanon wybitny poeta starożytnego chrześcijaństwa łacińskiego Aureliusz Prudencjusz Klemens ${ }^{8}$. Wzmianki na jej temat znaleźć można ponadto w historiograficznych dziełach In gloria Martyrum Grzegorza $\mathrm{z}$ Tours, Historia de Regibus Gothorum, Wandalorum et Suevorum Izydora z Sewilli oraz w kronice Hydacjusza ${ }^{9}$. Ważną grupę utworów poetyckich przywołujących postać św. Eulalii stanowi również kilka zachodnioeuropejskich hymnów z okresu od VI do VIII w., których głównym tematem jest pochwała czystości. Chodzi tu o De virginitate Wenancjusza Fortunatusa, noszący ten sam tytuł utwór Aldhelma z Malmesbury (znany w dwóch wersjach - poetyckiej i prozatorskiej) oraz Alma Deus Trinitas Bedy Czcigodnego ${ }^{10}$. Często przytaczanym źródłem jest także mowa, wy-

cattolica, t. 5, red. P. Paschini, Watykan 1950, kol. 806. Powyższe opracowania wymieniają „pierwszą" bazylikę w Meridzie jako centrum kultu św. Eulalii w dobie konstantyniańskiej, nie podając jednak żadnych szczegółowych wiadomości na ten temat. Natomiast w Martyrium recherches sur le culte des reliques et l'art chrétien antique, t. 1: Architekture, red. A. Grabar, Paris 1946, s. 122 przytoczono dodatkowo słowa Grzegorza z Tours, świadczące najprawdopodobniej o istnieniu w Meridzie - przy właściwym martyrium - również jakiegoś miejsca sakralnego na wolnym powietrzu: „À Mérida, en Espagne, à l’endroit où l'on vénère les reliques de sainte Eulalie, «sunt igitur ante eius altare, quo sancta membra tegintur, tres arbores...» (qui donnent lieu à un miracle)". Pisząc o bazylice św. Eulalii, na świadectwo literackie, ale tym razem Prudencjusza, powołuje się również M. Sotomayor y Muro, La Iglesia en la España romana, w: Historia de la Iglesia en España, t. 1: La Iglesia en la España romana y visigoda (siglos I-VIII), red. R. Garcia-Villoslada, Madrid 1979, s. $180,280$.

Na temat patronatów przypisywanych św. Eulalii - zob. D. H. Kerler, Die Patronate der Heiligen. Ein Alphabetisches Nachschlagebuch für Kirchen-, Kultur-, Kunsthistoriker, sowie für den praktischen Gebrauch des Geistlichen von..., Ulm 1905, s. 289, 291.

7 Zob. Bibliotheca Hagiographica Latina Antiquae et Mediae Aetatis adiderunt Socii Bollandiani, t. 1, Bruxellis 1989-1899, nr 2693, 2694, 2696, 2700, s. 405.

8 Zob. Aureliusz Prudencjusz Klemens, Wieńce męczeńskie (Peristephanon)..., dz. cyt., s. $183-197$.

9 Georgius Florentius Gregorius Turonienisis, De gloria beatorum Martyrum, w: S. Georgii Florentini Gregorii Turoniensis episcopi opera omnia, ed. J. P. Migne, Parisiis 1870, kol. 785 (Patrologiae Cursus Completus. Series Latina [dalej: PL], 71); Isidorus, Historia de Regibus Gothorum, Wandalorum et Suevorum, w: Sancti Isidori Hispalensis episcopi opera omnia, acc. J. P. Migne, Parisiis 1862, kol. 1066 (PL, 83).

10 Zob. Aldhelmus, Tractatus sive ejus operum pars secunda. De laudibus virginitatis sive de virginitate Sanctorum, w: Octavi Saeculi ecclesiastici Scriptores. Opera omnia, t. 1, 
głoszona przez św. Augustyna w dniu liturgicznego wspomnienia Eulalii między rokiem 410 a $412^{11}$. Wymienić wreszcie należy unikatową $L a$ Cantilène de Sainte Eulalie - utwór z IX stulecia, będący pierwszym dziełem napisanym w potocznym języku francuskim, a ściślej w jego dialekcie pikardyjsko-wallońskim ${ }^{12}$.

Paradoksalnie jednak pomimo istnienia licznych świadectw popularności owej postaci - a może właśnie za sprawą ich liczby i zróżnicowania - hagiografia staje przed problemem teoretycznego istnienia dwóch świętych z IV wieku o tymże imieniu i paralelnej biografii. Jedni czczą bowiem Eulalię z Meridy, a drudzy jej imienniczkę z Barcelony; zaś kwestia rzeczywistej egzystencji obu tych bohaterek stanowi przedmiot dyskusji historyków Kościoła i patrologów.

Losy św. Eulalii z Barcelony są bardzo podobne do dziejów świętej z Meridy, a porównując zachowane źródła, można znaleźć jedynie kilka różnic. Ma ona nie 12, a 13 (lub 14) lat, umiera w Barcelonie, ukrzyżowana z rozkazu namiestnika Dacjana, jej śmierć datuje się na 303 rok. Wszystkie pozostałe elementy historii obu męczennic są zbieżne. Właśnie to podobieństwo dało podstawę do sporów co do autentyczności świętej $\mathrm{z}$ Barcelony ${ }^{13}$. Dodatkowym argumentem $\mathrm{w}$ toczonych przez hagiogra-

acc. J. P. Migne, Parisiis 1863, kol. 146 (PL, 89); Aldhelmus, Poemata sive ejus operum pars tertia. De laudibus virginum, w: Octavi Saeculi ecclesiastici Scriptores. Opera omnia, t. 1, dz. cyt., kol. 273; Beda Venerabilis, Historia ecclesiastica, w: Venerabilis Bedae Anglo-Saxonis presbyteri opera omnia, t. 6, acc. J. P. Migne, Parisiis 1863, kol. 204 (PL, 95); Venantius Honorius Clementius Fortunatus, De virginitate (liber VIII, carmen III), w: Venanti Honori Clementiani Fortunati presbyteri Italici opera poetica, Monumenta Germaniae Historica inde ab anno Christi 500 usque ad annum 1500. Auctores Antiquissimi, t. 4, cz. 1, BerlinWeimar 1881 [przedruk 1961], s. 185.

11 Zob. Agustin, Sermo CCCXIIIG [313 G]. De die Sanctae Eulaliae, w: Obras Completas de San Agustin, t. 15: Sermones, cz. 5: Sermones sobre los mártires (273-338), Madrid 1984, s. 587-589.

${ }_{12}$ Zob. Recueil d'anciens textes bas-latins provençaux et français, red. P. Meyer, Paris 1874, s. 194 n.

${ }^{13}$ Zob. J. Boberg, Eulalia von Mérida (von Barcelona) Jungfrau, Mart. 10.12, w: Lexikon der christlichen Ikonographie, t. 6, Freiburg 1974, kol. 179n; A. Fàbrega-Grau, Eulalie de Barcelone (Sainte), w: Dictionnaire d'Histoire et de Geographie ecclesiastiques, t. 15, red. A. Baudrillart, Paris 1963, kol. 1381n; A. Fàbrega-Grau, Santa Eulalia de Barcelona: revision de un problema historico, Rome 1958; Z. Garciá-Villada, El problema de las dos 
fów dysputach jest fakt, iż do połowy VII wieku nie ma żadnej wzmianki o owej barcelońskiej Eulalii. Dopiero bowiem około 653 roku tamtejszy opat - biskup Quiricus ogłosił odnalezienie grobu miejscowej świętej i napisał ku jej czci hymn, tekst mszy oraz $A k t a^{14}$.

\section{Adnotacje na temat św. Eulalii} we wczesnośredniowiecznych łacińskich kalendarzach liturgicznych i martyrologiach

Pierwsza znana adnotacja na temat św. Eulalii z dzieł interesującego nas typu pochodzi z powstałego przed 476 rokiem Kalendarium Carthaginense (Kalendarza Kartagińskiego) i brzmi w sposób następujący:

Czwarte Idy Grudnia [10 XII] Świętej Eulalii ${ }^{15}$.

Autor rzeczonego spisu umiejscowił więc uroczystość św. Eulalii pod datą 10 grudnia, nie zaznaczył jednak, o którą z dwóch męczennic o tym imieniu chodzi. Zważywszy jednak na fakt, iż święta barcelońska pojawia się w tekstach patrystycznych dopiero od VII wieku, więc zapewne mowa tu o Eulalii z Meridy.

santas Eulalias, „Razón y Fe” 58 (1920), s. 166-186; A. F. Negri, M. Sotomayor, Eulalia, santa, martire in Spagna, w: Bibliotheca Sanctorum, t. 5, a cura di F. Caraffa, Roma 1964, kol. 208; V. Saxer, Eulalia di Barcellona, w: Dizionario patristico e di antichità cristiane, t. 1, a cura di A. Di Berardino, Roma 1983, kol. 1279.

${ }^{14}$ Zob. [Oficjum brewiarzowe] Die XII Februarii. In festo sanctae Eulaliae, virginis, Barchinonensis, w: Liturgia Mozarabica secundum regulam beati Isidori. Missale mixtum. Praefatione, notis et appendicibus. Breviarium Gothicum, t. 2, acc. J. P. Migne,Parisiis 1891, kol. 1099n (PL, 86).

15 Tłumaczenie własne. Kalendarium Carthaginense, w: Acta Martyrum. Theodorici Ruinart opera ac studio collecta, selecta atque illustrata accedunt praeterea in hac editione Acta SS. Firmi et Rustici, red. T. Ruinart, Ratisbonae 1859, s. 633: „IV. Id. Dec. Sanctae Eulaliae”. R. Aigrain, analizując tekst tegoż kalendarza, poczynił następującą uwagę: „Aucun des prétendus martyrs que revendiquait le schisme donatiste n'ayant trouvé place dans ce catalogue, il est permis de croire que nous avons là un calendrier catholique, et que la secte n'est pas intervenue dans sa rédaction". R. Aigrain, L'hagiographie. Ses sources. Ses méthodes. Son histoire, Paris 1953, s. 22. 
Po raz pierwszy natomiast wspomnienia liturgiczne obydwu męczennic hiszpańskich odnotowane zostały w pochodzących z VII wieku Kalendarium Gothicum (Kalendarzu Gockim) oraz Calendarium Mozarabicum (Kalendarzu Mozarabskim):

W przeddzień Id Lutego [12 II]. Eulalii dziewicy z Barcelony ${ }^{16}$.

Czwarte Idy Grudnia [10 XII]. Eulalii dziewicy i męczennicy ${ }^{17}$.

Spisy te lokalizują zatem święto Eulalii z Barcelony w dniu 12 lutego, zaś uroczystość jej imienniczki - a zapewne chodzi tu o postać z Meridy 10 grudnia. I taki właśnie układ najczęściej powtarzał się w późniejszych, średniowiecznych kalendarzach.

Przy czym wspomnieć na tym miejscu trzeba o niezwykle ciekawym choć całkowicie pomijanym w literaturze przedmiotu - wyjątku, jakim jest tzw. King Athelstan's Kalendar (Kalendarz króla Athelstana; rkps Galba, A XVIII). Dzieło to powstało na terenie Wysp Brytyjskich w pierwszej połowie X stulecia i wchodziło w skład małego psałterza, będącego własnością rzeczonego władcy saksońskiego Athelstana (zm. 940). Również i w tym przypadku św. Eulalia wymieniona została dwukrotnie, lecz pod jeszcze innym układem dat. Raz 10 grudnia:

\section{GRUDZIEŃ}

IV Idy Grudnia [10 XII] - dziesiąty [dzień miesiąca grudnia] współweseli się Eulalią czystą dziewicą ${ }^{18}$.

16 Tłumaczenie własne. Kalendarium Gothicum, w: Liturgia Mozarabica secundum regulam beati Isidori. Missale mixtum. Praefatione, notis et appendicibus. Breviarium Gothicum, t. 2, dz. cyt., kol. 38; Calendarium Mozarabicum saepius auctum, w: Liturgia Mozarabica secundum regulam beati Isidori. Missale mixtum. Praefatione, notis et appendicibus. Breviarium Gothicum, t. 1, ed. J. P. Migne, Parisiis 1862, kol. 96 (PL, 85): „Pridie Idus Februarii. Eulaliae virginis Barchinonensis".

17 Tłumaczenie własne. Kalendarium Gothicum..., dz. cyt., kol. 44; Calendarium Mozarabicum saepius auctum..., dz. cyt., kol. 104: „IV ante Idus Decembriis. Eulaliae virginis et martyris".

18 Tłumaczenie własne. R. T. Hampson, Medii Aevi Kalendarium or dates, charters, and customs of the Middle Ages, with kalendars from the tenth to the fifteenth century 
Powtórnie zaś w dniu 30 marca:

\section{MARZEC}

III Kalendy Marca [30 III] - w trzecie [kalendy marca] wysokości nieba [radują się] Eulalią ${ }^{19}$.

W tym przypadku więc liczba adnotacji wskazuje, iż w obchodach liturgicznych uwzględniane były dwie święte Eulalie, lecz treść owych zapisków nie pozwala połączyć daty z konkretną postacią. Tak czy inaczej kalendarz ten poświadcza istnienie kultu męczennic hiszpańskich w saksońskiej Anglii w końcu okresu patrystycznego.

Biorąc natomiast pod uwagę zespół wczesnośredniowiecznych łacińskich martyrologiów, elogium św. Eulalii znaleźć można już w najwcześniejszym - bo pochodzącym z połowy $\mathrm{V}$ wieku, a będącym tłumaczeniem starszego jeszcze tekstu greckiego - Martyrologium Hieronymianum (Martyrologium Hieronima) ${ }^{20}$. Pod datą 12 lutego podaje ono następujący zapis:

W Italii Donata, Herakliusza, Wincentego, Zuzanny, Urbany, Donaty, Eula li i, których dzieje są posiadane [znane ${ }^{21}$.

Autor przytoczonego tu tekstu wymienił więc św. Eulalię w szeregu męczenników z pierwszych wieków chrześcijaństwa - obok Donata, Herakliusza, Wincentego, Zuzanny, Urbany i Donaty - nie podając jednak

and an alphabetical digest of obsolete names of days: forming a glossary of the dates of the Middle Ages, with tables and other aids for ascertaining dates, cz. 1, London 1841, s. 419: „DECEMBER. IIII id. - Decima Eulalia congaudet virgine casta”.

19 Tłumaczenie własne. R. T. Hampson, Medii Aevi Kalendarium..., s. 402: „MARTIUS. III kl. - Trinis Eulalia caelum penituerat altum".

${ }^{20}$ Hieronimowe autorstwo rzeczonego Martyrologium powszechnie podawane jest w wątpliwość. Najprawdopodobniej bowiem tłumacz tego tekstu przypisał je tylko znanemu ojcu Kościoła, aby zapewnić dziełu większy autorytet i łatwiejszą akceptację. Zob. A. Witkowska, Kalendarze..., dz. cyt., s. 540; Martyrologium Rzymskie..., dz. cyt., s. 9n.

${ }^{21}$ Tłumaczenie i podkreślenie autorki. H. Leclercq, Eulalie de Mérida et de Barcelone (les Saintes)..., dz. cyt., kol. 725: „In Italia Donati Heracli Vincenti Susanne Urbane Donate Eulalie quorum gesta habentur". 
żadnych bliższych szczegółów odnośnie do tych postaci ${ }^{22}$. A co zaskakujące, owa - bardzo zresztą lapidarna - adnotacja pozostawia wrażenie, iż święta ta pochodziła nie z Hiszpanii, lecz z Italii lub ewentualnie - że tam właśnie zlokalizowany był główny ośrodek jej kultu. Opinia ta wszakże nie znajduje potwierdzenia w żadnym innym źródle i powoduje, iż zapis ów uchodzi za niepewny. Pomimo tego należy pamiętać, iż potwierdza on istnienie kultu św. Eulalii w połowie V stulecia oraz informuje o ówczesnym zwyczaju obchodzenia jej święta w dniu 12 lutego.

Mniej już wątpliwości budzą adnotacje, jakie na temat św. Eulalii (lub też dwóch męczennic o tym imieniu) poczynione zostały przez autorów tzw. martyrologiów historycznych. Ów nowy typ tego rodzaju piśmiennictwa zainicjował na początku VIII stulecia Beda Wielebny (zm. 735) ${ }^{23}$, który dokonał w imię prawdy historycznej selekcji tradycyjnie dotychczas uznawanych świętych i świąt. Przy czym, rezygnując z uwzględnienia w swym martyrologium wielu - nieautentycznych jego zdaniem postaci, zadbał jednak o to, aby na temat tych, które pozostały, podać choć kilka bardziej szczegółowych informacji ${ }^{24}$. Zaś stosując owe nowatorskie jak na ówczesne czasy metody, uznał za zgodne z realiami dziejowymi istnienie tylko jednej św. Eulalii i zapisał na jej temat, co następuje:

\section{IDY GRUDNIA [10 XII]}

Narodzenie [dla nieba] św. Eulalii, dziewicy, w Barcelonie, mieście Hiszpanii, pod sądem Dacjana: która - kiedy miała 13 lat - po wielu torturach

${ }^{22}$ Krótkie notki na temat niektórych spośród wymienionych tu świętych podają m.in.: co do postaci św. Donata - H. Fros, Martyrologium..., dz. cyt., s. 90; co do postaci św. Wincentego - W. Zaleski, Święci na każdy dzień, Warszawa 2001, s. 49n; co do postaci św. Zuzanny - W. Zaleski, Święci na każdy dzień, dz.cyt., s. 832.

${ }^{23}$ Zob. R. Skaliński, Beda Venerabilis. The great English historian (673-735), Toruń 2009; Beda Wielebny albo Czcigodny (Beda Venerabilis), w: Słownik wczesnochrześcijańskiego piśmiennictwa, red. J. M. Szymusiak, M. Starowieyski, Poznań 1971, s. 90-95.

${ }^{24}$ Martyrologium Bedy składa się w sumie ze 114 notatek historycznych na temat poszczególnych świętych i rozpoczyna się od dnia 1 stycznia (podczas gdy dzieło przypisywane św. Hieronimowi zaczyna się od 25 grudnia). Natomiast bazę źródłową, na której opierał się anglosaski historiograf, stanowiły: Pasje męczenników, świadectwa Euzebiusza z Cezarei (w tłumaczeniu Rufina), Martyrologium Hieronima oraz Synaxarion Konstantynopolitański. Zob. A. Bober, Studia i teksty patrystyczne, Kraków 1967, s. 111; Beda Wielebny albo Czcigodny..., dz. cyt., s. 94. 
została stracona [ścięta?] i po oddzieleniu od ciała jej głowy widziana była gołębica $\mathrm{z}$ ciała jej uwolniona ${ }^{25}$.

Z powyższego cytatu wynika, iż według opinii anglosaskiego historiografa św. Eulalia pochodziła z Barcelony i mając lat trzynaście, została ścięta z rozkazu namiestnika Dacjana. Przy czym w tychże szczegółach Beda odbiega od większości starożytnych autorów. Najczęściej bowiem pomijają oni imię cesarskiego urzędnika, który wydał wyrok, i akcentują, iż bohaterka poniosła śmierć w płomieniach ${ }^{26}$. Z kolei Prudencjusz wyraźnie przypisuje jej wiek lat dwunastu, nie zaś trzynastu ${ }^{27}$. W zgodzie $\mathrm{z}$ innymi przekazami pozostaje natomiast zamieszczone w rzeczonym martyrologium wspomnienie o cudownym zdarzeniu, jakie miało towarzyszyć śmierci męczennicy (dusza świętej pod postacią gołębicy wyfrunęła z jej umęczonego ciała ${ }^{28}$. Na koniec warto zaznaczyć, iż Beda nie tylko wyraźnie wskazał, że chodzi mu o Eulalię z Barcelony, ale także

25 Tłumaczenie własne. Edition pratique des Martyrologes de Bede, de l'Anonyme Lyonnais et de Florus, red. J. Dubois, G. Renaud, Paris 1976, s. 221:

„IV IDUS DECEMBRIS

Natale sanctae Eulaliae virginis, in Barcelona, civitate Hispaniae, sub Daciano praeside: quae, cum esset tredecim annorum, post plurima tormenta decollata est; et resiliente ab ea capite, columba de corpora ejus exire visa est".

${ }^{26}$ A co ciekawe, i sam Beda w poemacie Alma Deus Trinitas podkreślił, iż św. Eulalia zginęła na stosie. Możliwe więc, iż autorowi chodziło o dwie różne męczennice o tym samym imieniu. Ale jeśli tak, to pozostaje pytanie, czemu w Martyrologium uwzględnił on tylko jedną z nich. Zob. Beda Venerabilis, Historia ecclesiastica..., dz. cyt., kol. 204: „Eulalia et perfert ignibus usta feris".

${ }_{27}$ Zob. Prudentius Aurelius Clementius, Hymnus III. De Martyrio s. Eulaliae virginis Emeritensis, w: Acta Martyrum. Theodorici Ruinart opera ac studio collecta, selecta atque illustrata accedunt praeterea in hac editione Acta SS. Firmi et Rustici, ed. T. Ruinart, Ratisbonae 1859, s. 480, wers 11-14: „Curriculis tribus atque novem/ Tres hyemes quater attigerat,/ Cum crepitante pyra trepidos/ Terruit aspera carnifices”.

${ }^{28}$ Ptak ten symbolizuje niewinność i łagodność, zaś w ikonografii chrześcijańskiej zwłaszcza wizygockiej i romańskiej - był ponadto uosobieniem duszy, opuszczającej po śmierci ciało męczennika. Zob. J. E. Cirlot, Słownik symboli, przekł. I. Kania, Kraków 2000, s. 140; D. Forstner, Świat Symboliki Chrześcijańskiej, przekł. W. Zakrzewska, P. Pachciarek, R. Turzyński, Warszawa 1990, s. 232; R. Gilles, Le Symbolisme dans l'Art Religieux, Paris 1943, s. 27n; W. Kopaliński, Słownik mitów i tradycji kultury, Warszawa 1985, s. 330; W. Kopaliński, Stownik symboli, Warszawa 1990, s. 100; M. Oesterreicher-Mollwo, Leksykon Symboli Herdera, przeł. J. Prokopiuk, Warszawa 1992, s. 45; L. Réau, Iconographie de l’art 
przeniósł jej wspomnienie - w stosunku do wcześniejszego tekstu przypisywanego Hieronimowi - na dzień 10 grudnia.

Dzieło anglosaskiego historyka po ponad 150 latach doczekało się kontynuacji pod postacią Martyrologium Florusa. Jego autorem był diakon z Lyonu (zm. ok. 860), którego ingerencja w tekst Bedy polegała właściwie tylko na rozszerzeniu elogii niektórych świętych ${ }^{29}$. Zmiany takie dokonane zostały między innymi w tekście dotyczącym św. Eulalii, stąd "anglosaski” zapis z dnia 10 grudnia wzbogacony został o adnotację następującej treści:

Które [to] błogosławione ciało [św. Eulalii] przez trzy dni z rozkazu sędziego wisiało na szafocie. Lecz któremu to rozkazowi ludzie byli posłuszni, niebo się sprzeciwiło. Bowiem śniegiem z góry ciało dziewczyny posypane [zostało], chociaż [bowiem] to ciało z obu stron przyłożony ogień pochodni swoim żarem spalił, [to jednak] Bożą łaską śnieżnobiałą pokrywą zostało [ono] okryte. I tak przez chrześcijan pokornie niesione i pobożnie przeznaczone do złożenia pod świętym ołtarzem, chwałą cudów jest sławne ${ }^{30}$.

Florus dołożył więc do tekstu Bedy informacje o cudownym opadzie śniegu, który miał przykryć pozostawione na widoku publicznym ciało męczennicy ${ }^{31}$. Wspomina także o pogrzebie, jaki wierni lokalnego

chrétien, t. 3: Iconographie des Saints, cz. 1, Paris 1958, s. 463; V. Schauber, H. M. Schindler, Ilustrowany leksykon świętych, przekł. P. Tkaczyk, R. Zajączkowski, Kielce 2002, s. 173.

${ }^{29}$ Lapidarne notki na temat Florusa z Lyonu i jego spuścizny pisarskiej podają: M. Banaszak, Historia Kościoła katolickiego, t. 2: Średniowiecze, Warszawa 1989, s. 50; M. Zahajewicz, Florus z Lyonu, diakon, w: Encyklopedia katolicka, t. 5, Lublin 1989, kol. 349; Martyrologium rzymskie..., dz. cyt., s. 12.

${ }^{30}$ Tłumaczenie własne. Edition pratique des Martyrologes..., dz. cyt., s. 221:

„Cujus beatum corpus per triduum jussu praesidis pependit in ligno. Sed cui humana fuerant obsequia denegata caelestia fuerunt munera concessa. Nam nix desuper puellae corpus aspersus, ut quod ex utraque parte appositus ignis ardoris sui incendio conflagraverat, nivali candore coopertum divina gratia dealbaret. Sicque a christianis reverenter ablata et devotione debita sub sacro altari deposita, miraculorum gloria illustratur."

${ }^{31}$ Część hagiografów widzi w tym zjawisku dowód na to, iż św. Eulalia poniosła śmierć w porze zimowej. Inni zaś wręcz przeciwnie - zaznaczają cudowność tegoż wydarzenia przez podkreślenie, iż miało ono miejsce w środku lata. Zob. R. Cammilleri, Wielka księga Świętych Patronów, tłum. M. Radomska, Kielce 2002, s. 188; M. Henrion, Histoire 
kościoła uczynili świętym szczątkom, oraz o złożeniu relikwii męczennicy pod ołtarzem kościelnym. Przy czym ta ostatnia informacja wskazuje na istnienie świątyni, prawdopodobnie pod wezwaniem św. Eulalii, w której doznawałaby ona szczególnej czci ${ }^{32}$. Zastanawiające jest wreszcie sformułowanie o pozostawieniu $\mathrm{z}$ rozkazu urzędnika ciała bohaterki „pependit in ligno". W pierwszym rzędzie sugerowałoby ono bowiem fakt, iż męczennica ta została powieszona, ewentualnie ukrzyżowana. A co za tym idzie, zwrot ten pozostawałby w sprzeczności z zapisem Bedy, wyraźnie mówiącym o ścięciu dziewczyny. Dopiero zaś w szerszym ujęciu można odczytywać wyraz „ligno” w znaczeniu „szafotu” w ogóle i próbować tłumaczyć całość jako zostawienie ciała z odciętą głową na miejscu kaźni.

Nowością w stosunku do anglosaskiego martyrologium jest także adnotacja umieszczona przez diakona liońskiego pod datą 12 lutego, a mająca następującą treść:

\section{IDY LUTEGO [12 II]}

W Hiszpanii, mieście Barcelonie, narodziny [dla nieba] świętej Eulalii, dziewicy i męczennicy, która poniosła [męczeństwo] w czasach imperatora Dioklecjana, pod namiestnikiem Hiszpanii Dacjanem ${ }^{33}$.

Notatka ta - mówiąca o męczeństwie św. Eulalii z Barcelony - ponownie przywołuje postać namiestnika Dacjana oraz wprowadza po raz pierwszy informacje, iż rzeczone wydarzenia miały miejsce za panowania cesarza Dioklecjana ${ }^{34}$.

Ecclésiastique depuis la création jusqu’au pontificat de Pie IX, t. 13: Depuis la dixième persécution générale suscitée a l'Église l'an 303 jusqu'au pontificat de saint Libère, Paris 1858, kol. 180.

${ }_{32} \mathrm{O}$ zwyczaju, czy wręcz obowiązku, umieszczania relikwii pod ołtarzami kościołów piszą m. in.: K. Bihlmeyer, H. Tüchle, Historia Kościoła, t. 1: Starożytność chrześcijańska, tłum. J. Klenowski, Warszawa 1971, s. 348; M. Starowieyski, Męczeństwo, w: Męczennicy, Kraków 1991, s. 116 (Ojcowie Żywi, 9).

33 Tłumaczenie własne. Edition pratique des Martyrologes..., dz. cyt., s. 33: „II IDUS FEBROARII

In Hispaniis, civitate Barcinonae, natale sanctae Eulaliae virginis et martyris, quae est tempore Diocletiani imperatoris, sub praefecto Hispaniarum Datiano".

${ }^{34}$ Chodzi więc o ostatnie wielkie prześladowanie chrześcijan $\mathrm{z}$ lat 303-311. Zob. P. Batiffol, La paix constantinienne et le catholicisme, Paris 1914, s. 153-180; J. E. Derras, Histoire 
Florus podaje więc dwie daty, z którymi związana była uroczystość św. Eulalii - utrzymany za Bedą dzień 10 grudnia oraz 12 lutego, przejęty najprawdopodobniej ze starszej, Hieronimowej jeszcze tradycji. Jak się wydaje, w obydwu przypadkach chodzi o upamiętnienie męczennicy z Barcelony, nie ma tu natomiast żadnego wspomnienia o postaci z Meridy.

W dużej zależności od dzieła Bedy pozostaje również napisane około 800 roku Martyrologium z Lyonu ${ }^{35}$. Na temat św. Eulalii przedstawia ono, podobnie jak Florus, dwie notatki. Pierwsza, zamieszczona pod dniem 12 lutego, mówi:

W Hiszpanii, mieście Barcelonie narodziny [dla nieba] świętej Eulalii dziewicy ${ }^{36}$.

Druga zaś, datowana na 10 grudnia, podaje:

W pobliżu Emerity [Meridy], miasta w Hiszpanii, narodzenia [dla nieba] świętej Eulalii dziewicy, która - kiedy miała trzynaście lat - na rozkaz sędziego Dacjana wielu torturom została poddana. Ostatecznie na katuszach trzymana i dławiona haustem ognia, kiedy małe pochodnie płonące z obu stron do [jej] ciała przykładane były, ducha oddała i wtedy chrześcijanie [duszę jej] spostrzegają w postaci gołębicy białej lecącej do nieba ${ }^{37}$.

générale de l'Église depuis le commencement de lère chrétienne jusqu’à nos jours, t. 1, Paris 1878, s. 278; L. Duchesne, Storia della Chiesa antica, t. 2, Milano 1907, s. 9-38; A. Ehrhard, Urkirche und Frühkatholizismus, Bonn 1951, s. 258-281; L. Homo, Les empereurs romains et le christianisme, Paris 1931, s. 72-84; M. Sordi, Il cristianesimo e Roma, Bologna 1965, s. 333-352; J. Umiński, Historia Kościoła, t. 1: Chrześcijańska starożytność i wieki średnie, Opole 1949, s. 57-59. Wyżej wymienione publikacje analizują przyczyny wybuchu ostatniego wielkiego prześladowania wyznawców Chrystusa w cesarstwie rzymskim, omawiają również etapy jego rozprzestrzeniania się na coraz to rozleglejsze obszary Imperium oraz kolejne wydawane wówczas edykty antykościelne. $Z$ dużą nieraz dozą naturalizmu ukazują ponadto specyficzne rodzaje tortur - właściwe dla poszczególnych prowincji - jakim poddawano chrześcijan, wyliczając przy tym imiona najbardziej znanych męczenników tego okresu.

${ }_{35}$ Zob. A. Witkowska, Kalendarze..., dz. cyt., s. 541.

36 Tłumaczenie własne. Edition pratique des Martyrologes..., dz. cyt., s. 33: „In Hispaniis, civitate Barcinone, natale sanctae Eulaliae virginis".

37 Tłumaczenie własne. Edition pratique des Martyrologes..., dz.cyt., s. 221: „Apud Emeritam, Hispaniae civitatem, natale sanctae Eulaliae virginis: quae, cum esset annorum 
Z przytoczonych powyżej zapisków wynika więc, iż autorowi Martyrologium z Lyonu praktycznie nic więcej nie wiadomo na temat św. Eulalii z Barcelony, poza tym, że pozostała ona w stanie dziewiczym. Natomiast dłuższej nieco adnotacji doczekała się męczennica z Meridy. W tym przypadku jednak widoczna jest znaczna zbieżność informacji z tymi, które Beda podawał odnośnie do świętej barcelońskiej. Bowiem bohaterka z Emerita Augusta również ma trzynaście lat, także ginie z rozkazu sędziego o imieniu Dacjan, a po jej śmierci widziana jest dusza ulatująca do nieba pod postacią gołębicy. Jedyna - acz istotna - różnica to fakt, iż według Martyrologium z Lyonu umarła ona nie od miecza czy na krzy$\dot{z} u$, lecz w płomieniach.

Anonimowy autor lioński po raz pierwszy więc w tego typu dziele wprowadził dwie święte Eulalie, z których każda ma własną uroczystość kościelną: ta $\mathrm{z}$ Barcelony w dniu 12 lutego i ta z Meridy - 10 grudnia. Taki stan rzeczy natomiast - mimo iż pozostaje w sprzeczności z wcześniejszymi martyrologiami - zgadza się całkowicie z informacjami, które podawane są przez przytoczone powyżej kalendarze liturgiczne mozarabski i gocki.

Z kolei z połowy IX stulecia pochodzi Martyrologium Hrabanusa Maura. Powstało ono na akwizgrańskim dworze Karola Wielkiego i przypisywane jest jednemu z najwybitniejszych przedstawicieli doby renesansu karolińskiego ${ }^{38}$. Mimo to tekst ów nie odcisnął silniejszego piętna na piśmiennictwie tegoż okresu, gdyż ma on charakter dzieła ściśle kompilatorskiego i niewiele zawiera własnych uzupełnień autora. Dlatego też notatka, jaką tu zamieszczono odnośnie do postaci św. Eulalii, jest wiernym cytatem adnotacji Bedy, nie tylko co do treści, ale i co do lokalizacji

tredecim, jussu Daciani praesidis plurima tormenta perpessa, novissime in equuleo suspensa et exungulata, faculis ardentibus ex utroque latere appositis, hausto igne, spiritum reddidit et, cernentibus christianis, in specie columbae niveae caelum petiit".

${ }_{38}$ Zob. W. Bühne, Hrabanus Maurus und seine Schule, Fulda 1980; S. Haarländer, Rabanus Maurus zum Kennenlernen, Mainz 2006; R. Kottje, H. Zimmermann, Hrabanus Maurus. Lehrer, Abt und Bischof, Mainz-Wiesbaden 1982; R. Savigni, Tradizione patristica e cultura carolingia in alcune opere esegetiche di Alcuino e Rabano Mauro, Bologna 1991; W. Weber, Rabanaus Maurus in seiner Zeit, Mainz 1980; Hrabanus Maurus und seine Schule. Fertschrift der Rabanus-Maurus-Schule 1980, Fulda 1980. 
w kalendarzu ${ }^{39}$. Przeciwnie więc do innych martyrologiów z IX wieku datę 10 grudnia połączył Hraban z męczennicą z Barcelony, nie zaś z jej imienniczką z Meridy. A co ciekawe, tej ostatnie w ogólnie nie uwzględnił; podobnie jak zbył milczeniem wspomnienie Eulalii, przypisywane przez Florusa i Martyrologium z Lyonu na dzień 12 lutego.

Kolejne, już nieco późniejsze martyrologium historyczne wyszło spod pióra benedyktyna i arcybiskupa Vienne - św. Adona (zm. 875) ${ }^{40}$. Również i ono stanowi jedynie nowe opracowanie dzieł Bedy, Florusa oraz anonima $\mathrm{z}$ Lyonu. Stąd też zamieszczone tu adnotacje dotyczące postaci św. Eulalii nie wnoszą nic nowego. Adon opowiedział się za istnieniem dwóch męczennic o tym imieniu, przyjmując dla świętej barcelońskiej zapis Florusa z dnia 12 lutego. Zaś w przypadku bohaterki z Meridy podał dosłowny cytat $\mathrm{z}$ notatki zamieszczonej pod datą 10 grudnia w Martyrologium z Lyonu i dołączył do niej zapisek Florusa z tegoż dnia - ten, który w oryginale uzupełniał adnotację Bedy ${ }^{41}$.

Praktycznie równolegle $\mathrm{z}$ wyżej wymienionym powstało Martyrologium Usuarda. Jego autor, rzeczony Usuard (zm. ok. 875), był jednym z mnichów w opactwie St. Germain-des-Prés pod Paryżem i opracował

39 Zob. Raban Maurus, Martyrologium, w: B. Rabani Mauri Fuldensis abbatis archiepiscopi opera omnia, t. 4, acc. J. P. Migne, t. 110, Parisiis 1864, kol. 1185 (PL, 110).

${ }^{40}$ Pisarz ten najprawdopodobniej jest także autorem tzw. Vetus Romanum Martyrologium (Dawnego Martyrologium Rzymskiego). Aż do XIX wieku uchodziło ono bowiem za dzieło starożytne, które rzekomo zostało przesłane przez jednego z papieży jakiemuś biskupowi Akwilei, zaś Ado miał je tylko przekopiować. Obecnie zaś - za sprawą badań $\mathrm{H}$. Quentina - wykazano, iż tekst ten wcale nie pochodzi z Rzymu, lecz został napisany w IX wieku przez samego hierarchę z Vienne. Zob. W. Urban, Adon, Ado, św., w: Encyklopedia katolicka, t. 1, red. F. Gryglewicz, R. Łukaszyk, Z. Sułkowski, Lublin 1973, kol. 92; Martyrologium Rzymskie..., dz. cyt., s. 13.

${ }^{41}$ Zob. Le Martyrologe d'Adon. Ses deux familles. Ses trois recensions. Texte et commentaire, red. J. Dubois, G. Renaud, Paris 1984, s. 84, 411n. Jedynie w trzech miejscach możliwe są do zaobserwowania drobne różnice między tekstem Adona i Florusa. Nie mają one jednak charakteru merytorycznego lecz czysto językowy i wynikać mogą z błędów kopisty. Chodzi o fragment: „Nam nix desuper corpus puellae adspersit, ut quod ab utraque parte appositus ignis ardoris sui incendio conflagraverat, nivali candore coopertum divina gratia dealbaret". Le Martyrologe d’Adon..., dz. cyt., s. 412. Podkreślenia własne - wskazują miejsca odbiegające od wersji Florusa. 
swe dzieło na zlecenie króla Karola Łysego ${ }^{42}$. Sformułowane przez niego elogia zawierają wszystkie ważniejsze wiadomości podawane we wcześniejszych martyrologiach, czasem nawet mają obfitsze od nich objaśnienia historyczne, a przy tym cechuje je zwięzłość. Dobrym przykładem tego stylu pisarskiego są adnotacje, jakie poczynił Usuard odnośnie do postaci św. Eulalii. Pod datą 12 lutego zamieścił on bowiem następujący tekst:

W Hiszpanii narodzenia [dla nieba] świętej Eulalii dziewicy, o której wiadomo, że w czasach imperatora Dioklecjana koronę chwalebną męczeństwa przyjęła w mieście Barcelonie ${ }^{43}$.

\section{Zaś na dzień 10 grudnia podał poniższą notatkę:}

W Hiszpanii, mieście Emerita, męczeństwo świętej Eulalii dziewicy, która - kiedy miała lat trzynaście - za wyznanie [wiary w] Chrystusa na rozkaz sędziego Dacjana wiele tortur przecierpiała. Ostatecznie na katuszach trzymana i dławiona haustem ognia, kiedy małe pochodnie zapalone do obu stron [jej] ciała przykładane były, ducha oddała ${ }^{44}$.

Idąc więc za Martyrologium z Lyonu oraz za tekstem Adona, Usuard przyjął istnienie dwóch świętych Eulalii oraz przypisane im w tych dziełach daty wspomnień liturgicznych. Przy czym na temat męczennicy z Barcelony (święto 12 lutego) podał wszystkie informacje, jakie zamieszcza Adon, tyle że ujął je innymi słowy. Natomiast w przypadku świętej

42 Warto w tym miejscu zaznaczyć, iż właśnie Martyrologium Usuarda było podstawą opracowanego przez kard. G. Sirleto na polecenie papieża Grzegorza XIII Martyrologium Romanum, które obowiązywało w całym Kościele od 1584 roku praktycznie aż do Vaticanum II. Zob. A. Witkowska, Kalendarze..., dz. cyt., s. 541.

${ }^{43}$ Tłumaczenie własne. Le Martyrologe d'Usuard, red. J. Dubois, Paris 1965, s. 179: „In Hispaniis, natalis sanctae Eulaliae virginis, quam constat tempore Dioclitiani imperatoris gloriosam martyrii accepisse coronam, civitate Barcinona".

44 Tłumaczenie własne. Le Martyrologe d’Usuard, dz. cyt., s. 356: „In Hispania, civitate Emerita, passio sanctae Eulaliae virginis, quae cum esset annorum tredecim, pro confessione Christi iussu Datiani praesidis plurima tormenta perpessa est. Novissime in equuleo suspensa et exungulata, faculis ardentibus ex utroque latere appositis, austo igne spiritum reddidit". 
z Meridy (uroczystość 10 grudnia) poszedł za anonimowym autorem z Lyonu, rezygnując jedynie z podawanej przez niego informacji o cudownym ukazaniu się gołębicy. Zamiast tego zaś podkreślił silnie, iż Eulalia poniosła śmierć za wyznanie wiary w Chrystusa.

Wreszcie na przełomie IX i X stulecia powstało Martyrologium autorstwa mnicha z Saint-Gall, Notkera Balbulusa (Jąkały) (zm. 912) ${ }^{45}$. Przy czym - podobnie jak dzieła Hrabana Maura i Adona - ma ono charakter kompilatorski, a do tego cechuje się niekompletnością. Nie zachowało się bowiem - albo też nigdy nie zostało zrealizowane - opracowanie końcowych miesięcy roku, w tym grudnia. Dlatego też trudno stwierdzić, czy autor miał zamiar uwzględnić wspomnienie św. Eulalii z Meridy, przypisywane przez Martyrologium z Lyonu, Adona i Usuarda na dzień 10 grudnia. W tekście dzieła - pod datą 12 lutego - znajduje się natomiast notatka odnośnie do męczennicy z Barcelony, która jest jednak dokładnym cytatem adnotacji uczynionej na ten dzień przez Florusa ${ }^{46}$.

\section{Zakończenie}

Podsumowując, należy zauważyć, iż przywołane zapisy z kalendarzy liturgicznych pochodzą z dokumentów należących do czterech różnych kręgów kulturowych: północnoafrykańskiego, gockiego (czy ściślej wizygockiego), iberyjskiego oraz anglo-saksońskiego. Powstały one na przestrzeni pięciu stuleci (między V a X wiekie). Fakt obecności w nich wspomnienia św. Eulalii świadczy więc o powszechności oraz niezależnej od wydarzeń historycznych trwałości kultu rzeczonej męczennicy. Sama forma zapisu, bardzo zwięzłego już ze swej natury, nie podlega tu silnemu zróżnicowaniu. Rozbieżności dotyczą natomiast dat, pod którymi umieszczano analizowane wspomnienie liturgiczne; choć w każdym

${ }^{45}$ Zob. H. Fros, Martyrologium..., dz. cyt., s. 72n.

46 Zob. Notker Balbulus, Martyrologium per anni circulum, w: Remigii monachi S. Germani Antissiodorensis beati Notkeri Balbuli, S. Galli monachi opera omnia, t. 1, acc. J. P. Migne, Parisiis 1884, kol. 1045 (PL, 131). 
przytoczonym przypadku stosowano zapis za pomocą rzymskiej rachuby dni według kalend, non $\mathrm{i}$ id $^{47}$.

Wyraźniejsze oboczności występują natomiast w przywołanych adnotacjach z wczesnośredniowiecznych martyrologiów łacińskich. Ich autorzy częściej uwzględniali bowiem w swych dziełach postać św. Eulalii z Barcelony niż jej imienniczki z Meridy. Ta ostatnia pojawia się - a i tak zawsze obok bohaterki barcelońskiej, nigdy zaś zamiast niej - jedynie w trzech (być może czterech) przypadkach na ogólną liczbę ośmiu omówionych w niniejszej pracy. Taki stan rzeczy można próbować tłumaczyć faktem, iż właśnie na przestrzeni od VII do IX stulecia miały miejsce odkrycia oraz translacje relikwii męczennicy z Barcelony, co też nadawało rozgłos tej postaci. Za pewne wyjaśnienie takiego stanu rzeczy może również posłużyć okupacja arabska, która w większym stopniu utrudniała funkcjonowanie ośrodka religijnego w Meridzie - jako leżącego w głębi ziem opanowanych przez muzułmanów - niż jego barcelońskiego odpowiednika. Paradoksalnie natomiast już pierwsze znaczące martyrologium doby nowożytnej pomija całkowicie barcelońską świętą, a za autentyczną uznaje jedynie Eulalię z Meridy ${ }^{48}$.

${ }^{47}$ Zob. E. Wipszycka, Chronologia, w: Vademecum historyka starożytnej Grecji i Rzymu, t. 1-2: Źródłoznawstwo starożytności klasycznej, red. E. Wipszycka, Warszawa 2001, s. 552.

${ }^{48}$ Chodzi tu o Martyrologium Romanum, o którym była już mowa w przyp. 42 niniejszego artykułu. Na temat św. Eulalii podaje ono następującą adnotację, umieszczoną pod datą 10 grudnia:

„Emeritae, in Hispania, passio sanctae Eulaliae Vírginis, quae, sub Maximiano Imperatore, cum esset annorum duodecim, ibi, jussu Daciani Praesidis, pro confessione Christi, plurima tormenta est perpessa; novissime, in equuleo suspensa et exungulata, faculis ardentibus ex utroque latere appositis, hausto igne, spiritum reddidit". Martyrologium Romanum Gregorii papae XIII iussu editum Urbani VIII et Clementis X auctoritate recognitum ac deinde anno MDCCXLIX Benedicti XIV opera ac studio emendatum et auctum, Watykan 1956, s. 399.

Tłumaczenie własne: „W Emericie, w Hiszpanii, męczeństwo świętej Eulalii, Dziewicy, która pod [rządami] imperatora Maksymiana - kiedy miała dwanaście lat - z rozkazu sędziego Dacjana, z powodu wyznania wiary w Chrystusa, najliczniejszymi torturami była męczona; nareszcie kiedy na katuszach [była] trzymana i biczowana, kiedy małe płonące pochodnie do obu [jej] boków były przykładane, ponieważ wchłonęła ogień, oddała ducha". 
Co do samej formy zapisu możliwe jest dostrzeżenie - wskazanych zresztą powyżej - zapożyczeń faktograficznych i stylistycznych. Przy czym brak tu „chronologicznej konsekwencji” w przejmowaniu ustalonej wcześniej wersji biogramu i wyraźnej linii rozwojowej tekstu. Zdarzało się bowiem, iż ten sam autor, pisząc adnotacje o Eulalii z Meridy i Barcelony, sięgał przy każdej z nich do innego pierwowzoru. Zaś poszczególne teksty ubogacane były lub skracane o szczegóły hagiograficzne bez zachowania jasnej reguły. Natomiast w miarę konsekwentnie lokalizowano wspomnienia liturgiczne w kalendarzu na dni 12 lutego i 10 grudnia. Zaś sama objętość elogii, pomijając lapidarną adnotację Pseudo-Hieronima, plasuje się na podobnym poziomie.

\section{Bibliografia}

Agustin, Sermo CCCXIIIG [313 G]. De die Sanctae Eulaliae, w: Obras Completas de San Agustin, t. 15: Sermones, cz. 5: Sermones sobre los mártires (273-338), Madrid 1984, s. 587-589.

Aigrain R., L'hagiographie. Ses sources. Ses méthodes. Son histoire, Paris 1953.

Aldhelmus, Poemata sive ejus operum pars tertia. De laudibus virginum, w: Octavi Saeculi ecclesiastici Scriptores. Opera omnia, t. 1, acc. J. P. Migne, Parisiis 1863, kol. 238-280 (Patrologiae Cursus Completus. Series Latina, 89).

Aldhelmus, Tractatus sive ejus operum pars secunda. De laudibus virginitatis sive de virginitate Sanctorum, w: Octavi Saeculi ecclesiastici Scriptores. Opera omnia, t. 1, acc. J. P. Migne, Parisiis 1863, kol. 105-162 (Patrologiae Cursus Completus. Series Latina, 89).

Aureliusz Prudencjusz K., Wieńce męczeńskie (Peristephanon), oprac. M. Starowieyski, Kraków 2006.

Banaszak M., Historia Kościoła katolickiego, t. 2: Średniowiecze, Warszawa 1989.

Batiffol P., La paix constantinienne et le catholicisme, Paris 1914.

Beck Hans-G., Kirche und theologische Literatur im byzantinischen Reich, München 1959.

Beda Venerabilis, Historia ecclesiastica, w: Venerabilis Bedae Anglo-Saxonis presbyteri opera omnia, t. 6, acc. J. P. Migne, Parisiis 1863, kol. 23-290 (Patrologiae Cursus Completus. Series Latina, 95). 
Beda Wielebny albo Czcigodny (Beda Venerabilis), w: Stownik wczesnochrześcijańskiego piśmiennictwa, red. J. M. Szymusiak, M. Starowieyski, Poznań 1971, s. 90-95.

Bibliotheca Hagiographica Latina Antiquae et Mediae Aetatis adiderunt Socii Bollandiani, t. 1, Bruxellis 1989-1899.

Bihlmeyer K., Tüchle H., Historia Kościoła, t. 1: Starożytność chrześcijańska, tłum. J. Klenowski, Warszawa 1971.

Bober A., Studia i teksty patrystyczne, Kraków 1967.

Boberg J., Eulalia von Mérida (von Barcelona) Jungfrau, Mart. 10.12, w: Lexikon der christlichen Ikonographie, t. 6, Freiburg 1974, kol. 179-180.

Bühne W., Hrabanus Maurus und seine Schule, Fulda 1980.

Calendarium Mozarabicum saepius auctum, w: Liturgia Mozarabica secundum regulam beati Isidori. Missale mixtum. Praefatione, notis et appendicibus. Breviarium Gothicum, t. 1, ed. J. P. Migne, Parisiis 1862, kol. 95-104 (Patrologiae Cursus Completus. Series Latina, 85).

Cammilleri R., Wielka księga Świętych Patronów, tłum. M. Radomska, Kielce 2002.

Cirlot J. E., Stownik symboli, przekł. I. Kania, Kraków 2000.

Cyprian, Listy, tłum. O. Szołdrski, red. E. Stanula, Warszawa 1969 (Pisma Starochrześcijańskich Pisarzy, 1).

Derras J. É., Histoire générale de l'Église depuis le commencement de lère chrétienne jusquà nos jours, t. 1, Paris 1878.

Drabina J., Chrześcijaństwo starożytne (do roku 313). Wybór tekstów źródłowych, Kraków 1983.

Duchesne L., Storia della Chiesa antica, t. 2, Milano 1907.

Dybowski M., Liturgika, Poznań-Warszawa-Lublin 1954.

Edition pratique des Martyrologes de Bede, de l'Anonyme Lyonnais et de Florus, red. J. Dubois, G. Renaud, Paris 1976.

Ehrhard A., Urkirche und Frühkatholizismus, Bonn 1951.

Fàbrega-Grau A., Eulalie de Barcelone (Sainte), w: Dictionnaire d'Histoire et de Geographie ecclesiastiques, t. 15, red. A. Baudrillart, Paris 1963, kol. 1380-1384.

Fàbrega-Grau A., Eulalie de Mérida (Sainte), w: Dictionnaire d'Histoire et de Geographie ecclesiastiques, t. 15, red. A. Baudrillart, Paris 1963, kol. 1384-1385.

Fàbrega-Grau A., Santa Eulalia de Barcelona: revision de un problema historico, Rome 1958. 
Fernández Caton J. M., Manifestaciones ascéticas en la iglesia hispano-romana del siglo IV, Leon 1962.

Ferretto Giuseppe, Note storico-bibliografiche di archeologia cristiana, Città del Vaticano 1942.

Forstner D., Świat symboliki chrześcijańskiej, przekł. W. Zakrzewska, P. Pachciarek, R. Turzyński, Warszawa 1990.

François A., Rok kościelny według Mszału. Uwagi teoretyczne i praktyczne, przeł. F. Żurowska, Kraków 1949.

Fros H., Martyrologium, czyli wspomnienia świętych przypadajace na poszczególne dni roku, Warszawa 1984.

Fros H., Sowa F., Księga imion i świętych, t. 2, Kraków 1997.

Fros H., Sowa F., Twoje imię, Kraków 1975.

Fros H., Wprowadzenie do Mszy o świętych, t. 1, Warszawa 1980.

Fros H., Wspomnienie świętych na każdy dzień roku. Martyrologium, Kraków 1992.

Garciá-Villada Z., El problema de las dos santas Eulalias, „Razón y Fe” 58 (1920), s. 166-186.

Georgius Florentius Gregorius Turonienisis, De gloria beatorum Martyrum, w: S. Georgii Florentini Gregorii Turoniensis episcopi opera omnia, ed. J. P. Migne, Parisiis 1870, kol. 703-800 (Patrologiae Cursus Completus. Series Latina, 71).

Gilles R., Le Symbolisme dans l'Art Religieux, Paris 1943.

Haarländer S., Rabanus Maurus zum Kennenlernen, Mainz 2006.

Hampson R. Th., Medii Aevi Kalendarium or dates, charters, and customs of the Middle Ages, with kalendars from the tenth to the fifteenth century and an alphabetical digest of obsolete names of days: forming a glossary of the dates of the Middle Ages, with tables and other aids for ascertaining dates, cz. 1, London 1841.

Henrion M., Histoire Ecclésiastique depuis la création jusqu'au pontificat de Pie IX, t. 13: Depuis la dixième persécution générale suscitée a l'Église l’an 303 jusqu’au pontificat de saint Libère, Paris 1858.

Homo L., Les empereurs romains et le christianisme, Paris 1931.

Hrabanus Maurus und seine Schule. Fertschrift der Rabanus-Maurus-Schule 1980, Fulda 1980.

Isidorus, Historia de Regibus Gothorum, Wandalorum et Suevorum, w: Sancti Isidori Hispalensis episcopi opera omnia, acc. J. P. Migne, Parisiis 1862, kol. 10571082 (Patrologiae Cursus Completus. Series Latina, 83). 
Kalendarium Carthaginense, w: Acta Martyrum. Theodorici Ruinart opera ac studio collecta, selecta atque illustrata accedunt praeterea in hac editione Acta SS. Firmi et Rustici, ed. T. Ruinart, Ratisbonae 1859, s. 632-634.

Kalendarium Gothicum, w: Liturgia Mozarabica secundum regulam beati Isidori. Missale mixtum. Praefatione, notis et appendicibus. Breviarium Gothicum, t. 2, acc. J. P. Migne, Parisiis 1862, kol. 37-44 (Patrologiae Cursus Completus. Series Latina, 86).

Kerler D. H., Die Patronate der Heiligen. Ein Alphabetisches Nachschlagebuch für Kirchen-, Kultur-, Kunsthistoriker, sowie für den praktischen Gebrauch des Geistlichen von..., Ulm 1905.

Kopaliński W., Słownik mitów i tradycji kultury, Warszawa 1985.

Kopaliński W., Słownik symboli, Warszawa 1990.

Kottje R., Zimmermann H., Hrabanus Maurus. Lehrer, Abt und Bischof, MainzWiesbaden 1982.

Kuźmak K., Jacniacka M., Eulalia z Méridy św., w: Encyklopedia katolicka, t. 4, red. R. Łukaszyk, L. Bieńkowski, F. Gryglewicz, Lublin 1985, kol. 1300-1301.

Le Martyrologe d'Adon. Ses deux familles. Ses trois recensions. Texte et commentaire, red. J. Dubois, G. Renaud, Paris 1984.

Le Martyrologe d'Usuard, red. J. Dubois, Paris 1965.

Leclercq H., Eulalie de Mérida et de Barcelone (les Saintes), w: Dictionnaire d'archéologie chrétienne et de liturgie, t. 5, cz. 1, red. F. Cabrol, H. Leclercq, Paris 1922, kol. 705-732.

Martyrium recherches sur le culte des reliques et l'art chrétien antique, t. 1: Architecture, red. A. Grabar, Paris 1946.

Martyrologium Romanum Gregorii papae XIII iussu editum Urbani VIII et Clementis $X$ auctoritate recognitum ac deinde anno MDCCXLIX Benedicti XIV opera ac studio emendatum et auctum, Watykan 1956.

Martyrologium rzymskie oraz elogia świętych i błogosławionych $z$ niektórych martyrologiów zakonnych, oprac. P. Turbak, Kraków 1967.

Narbutt O., Historia i typologia ksiag liturgicznych bizantyńsko-słowiańskich. Zagadnienie identyfikacji według kryterium treściowego, Warszawa 1979.

Negri Arnoldi F., Sotomayor M., Eulalia, santa, martire in Spagna, w: Bibliotheca Sanctorum, t. 5, a cura di F. Caraffa, Roma 1964, kol. 204-209.

Notker Balbulus, Martyrologium per anni circulum, w: Remigii monachi S. Germani Antissiodorensis beati Notkeri Balbuli, S. Galli monachi opera omnia, t. 1, 
acc. J. P. Migne, Parisiis 1884, kol. 1029-1164 (Patrologiae Cursus Completus. Series Latina, 131).

[Oficjum brewiarzowe] Die XII Februarii. In festo sanctae Eulaliae, virginis, Barchinonensis, w: Liturgia Mozarabica secundum regulam beati Isidori. Missale mixtum. Praefatione, notis et appendicibus. Breviarium Gothicum, t. 2, acc. J. P. Migne, Parisiis 1891, kol. 1099-1102 (Patrologiae Cursus Completus. Series Latina, 86).

Oesterreicher-Mollwo M., Leksykon Symboli Herdera, przeł. J. Prokopiuk, Warszawa 1992.

Onasch K., Liturgie und Kunst der Ostkirche in Stichworten unter Berücksichtigung der Alten Kirche, Leipzig 1981.

Ortiz de Urbina I., Eulalia, santa, martire, w: Enciclopedia Cattolica, t. 5, a cura di P. Paschini, Città del Vaticano, 1950, kol. 806.

Prudentius Aurelius Clementius, Hymnus III. De Martyrio s. Eulaliae virginis Emeritensis, w: Acta Martyrum. Theodorici Ruinart opera ac studio collecta, selecta atque illustrata accedunt praeterea in hac editione Acta SS. Firmi et Rustici, ed. T. Ruinart, Ratisbonae 1859, s. 480-482.

Raban Maurus, Martyrologium, w: B. Rabani Mauri Fuldensis abbatis archiepiscopi opera omnia, t. 4, acc. J. P. Migne, Parisiis 1864, kol. 1121-1188 (Patrologiae Cursus Completus. Series Latina, 110)

Réau L., Iconographie de l'art chrétien, t. 3: Iconographie des Saints, cz. 1, Paris 1958.

Recueil d'anciens textes bas-latins provençaux et français, red. P. Meyer, Paris 1874 .

Savigni R., Tradizione patristica e cultura carolingia in alcune opere esegetiche di Alcuino e Rabano Mauro, Bologna 1991.

Saxer V., Eulalia di Barcellona, w: Dizionario patristico e di antichità cristiane, t. 1, a cura di A. Di Berardino, Roma 1983, kol. 1279-1280.

Saxer V., Eulalia di Mérida, w: Dizionario patristico e di antichità cristiane, t. 1, a cura di A. Di Berardino, Roma 1983, kol. 1280.

Schamoni W., Das wahre Gesicht der Heiligen, München 1967.

Schauber V., Schindler H. M., Ilustrowany leksykon świętych, przekł. P. Tkaczyk, R. Zajączkowski, Kielce 2002.

Skaliński R., Beda Venerabilis. The great English historian (673-735), Toruń 2009.

Sordi M., Il cristianesimo e Roma, Bologna 1965. 
Sotomayor y Muro M., La Iglesia en la España romana, w: Historia de la Iglesia en España, t. 1: La Iglesia en la España romana y visigoda (siglos I-VIII), dir. R. Garcia-Villoslada, Madrid 1979, s. 7-400.

Starowieyski M., Męczeństwo, w: Męczennicy, wstępy, oprac. i wybór tekstów E. Wipszycka, M. Starowieyski, Kraków 1991, s. 84-142 (Ojcowie Żywi, 9).

Umiński J., Historia Kościoła, t. 1: Chrześcijańska starożytność i wieki średnie, Opole 1949.

Urban W., Adon, Ado, św., w: Encyklopedia katolicka, t. 1, red. F. Gryglewicz, R. Łukaszyk, Z. Sułkowski, Lublin 1973, kol. 92.

Venantius Honorius Clementius Fortunatus, De virginitate (liber VIII, carmen III), w: Venanti Honori Clementiani Fortunati presbyteri Italici opera poetica, Monumenta Germaniae Historica inde ab anno Christi 500 usque ad annum 1500. Auctores Antiquissimi, t. 4, cz. 1, Berlin-Weimar 1881 [przedruk 1961], s. 181-191.

Vincke J., Eulalia, hl., Jungfrau in Mérida, w: Lexikon für Theologie und Kirche, t. 3, Friburg 1957, kol. 1179-1180.

Weber W., Rabanaus Maurus in seiner Zeit, Mainz 1980.

Wipszycka E., Chronologia, w: Vademecum historyka starożytnej Grecji i Rzymu, t. 1-2: Źródłoznawstwo starożytności klasycznej, red. E. Wipszycka, Warszawa 2001, s. 542-559.

Witkowska A., Kalendarze - martyrologia, w: Słownik wczesnochrześcijańskiego piśmiennictwa, red. J. M. Szymusiak, M. Starowieyski, Poznań 1971, s. 538-542.

Zahajewicz M., Florus z Lyonu, diakon, w: Encyklopedia katolicka, t. 5, red. L. Bieńkowski, Lublin 1989, kol. 349.

Zaleski W., Święci na każdy dzień, Warszawa 2001.

\section{Abstract}

Presenting the names of the martyrs in commemorating liturgical calendars and martyrologies based on them is one of the earliest testimonies of their early cult. However, what is interesting is the process of changes that the annotations concerning the same character underwent in consecutive, future historical sources. The aim of the article is to analyse medieval Latin records presenting the Spanish martyress Saint Eulalia that lived in the period of Diocletian's persecutions of Christians. 
The analysis of the annotations in calendars (Carthaginian, the Gothic and Mozarabic) and martyrologists (Jerome, Bede, Florus, Hrabanus Maur, Adon, of Lyon, Usuard and Notker the Stammerer) is preceded by a brief presentation of the information concerning the life of the Saint that is available at present. Also, basic information concerning other written remains of her worship as well as hagiographic problem concerning the existence of two martyresses with the same name and a similar resume, but a different geographic location have been included in the article.

Słowa kluczowe: św. Eulalia, martyrologia, kalendarze liturgiczne, kult męczenników

Keywords: St. Eulalia, martyrologists, liturgicael calndars, the cult of the martyrs 